\title{
Connotation and Cultivation of Servant Leadership for Hotels
}

\author{
Si Chen
}

Tourism School, Shanghai Normal University, Shanghai, 200234, China

\begin{abstract}
Keywords: Leadership style, Servant leadership, Ethicality behavior, Hotel
\end{abstract}
\begin{abstract}
Servant leadership as a style of leadership with supply of work support and authorization as the starting point has huge influence on hotel industry. This paper settles ideal change of leadership and leadership style in recent decades, and more clearly discuss connotation, features and cultivation strategies of servant leadership. Through analysis of the importance of leadership style in hotel service, this paper hopes the idea of servant leadership can convey to more leadership practitioners of more hotels and make them create better job performance of hotel employees through servant leadership. This paper provides reference thought for creating new leader image.
\end{abstract}

\section{Introduction}

Modern hotel enterprises are influenced and restricted by surrounding general environment. They are influencing employees' moral outlook and values through efforts and their practice activities and outputting their enterprise culture so as to react upon the general environment. This paper expounds the following through settling leadership theories in recent 50 years: 1) how prominent views of leadership in different stages influence leaders' cognition of their roles and responsibilities; 2) after comparison, potential advantage of servant leadership for promoting hotel performance is proposed; 3) in allusion to hotel employment mechanism, hotels' training mode for servant leadership is proposed. This paper expects to facilitate leaders of hotel industry to envisage and respect such emerging leadership style through stressing servant leadership principle and practice value.

\section{Development of leadership theory}

Early leadership theory once considered successful leaders were considered to be “inborn”, rather than formation through acquisition. Such theory is called "great man" theory. In 1950s-1960s, Stogdill (Mann 1959; Stogdill 1948) and his supporters put forward no single standard could clearly classify leaders into efficient leaders and inefficient leaders. Such view leads leadership research emphasis to leaders' behaviors from leaders. Behavioristics scholars hold that individuals can become a leader through technological promotion and conscious behaviors. Meanwhile, different leadership styles which are deemed as different leadership styles are differentiated.

Leadership theory in recent 20 years expands the perspective to a specific environment and dynamic analysis of leaders with different features and working contents and those to be led. Contingency theory in this period considers during analysis of leadership effectiveness, specific environment change will distinctly decide influence and result of leadership behavior. Contingency theory requires leadership behavior changing according to the change in organizational environment and internal conditions in management practice.

Transformational leadership was proposed by Burns in 1978. Leadership effectiveness of transformational leadership is based on leaders' charm and stable working relationship. Transformational leaders improve their charm and establish cooperation relationship in the organization through creating open exchange atmosphere, building and supporting teamwork and proving necessary resources for the common goal. Effectiveness of transformational leadership depends on the ability of leaders to construct and maintain interpersonal relationship (Bass and Steidlmeier1999; Van Velsor and Ascalon 2008; Judi Brownell,2010).

Servant leadership as a concept related to transformational leadership starts to arouse people's attention over time. Servant leadership discusses and reconstructs previous research theories from 
two aspects: behavioral pattern of servant leaders and effects of servant leadership behaviors on the followers. The core of servant leadership is that how leaders' behaviors serve and authorize the products under employee motivation (Barbuto and Wheeler 2006; Farling, Stone,and Winston 1999; Judi Brownell,2010). It is pity that servant leadership behaviors fail to form a united definition till now.

Comparison of servant leadership and transformational leadership can help us better understand servant leadership. Russell (2001) considers leaders' values may be the most prominent feature to differ servant leadership from transformational leadership and other leadership styles. For example, transformational leadership pays attention to overall demand and goal of an organization, while servant leadership focuses on employees. Transformational leadership constructs "dynamic authorization" system, while servant leadership hopes to promote more stable internal environment through serving employees (Ehrhart 2004, 62). Many other researches distinguish servant leadership and transformational leadership from different aspects and gain the same conclusions.

Till now, measurement standards about servant leadership are still not united. Greenleaf believes servant leadership can be identified through listening, empathy, perception, authorization, prediction and commitment etc. (1998a). These are also servant leadership features widely accepted (Table 1).

Table 1. Behavioral expression of servant leadership

\begin{tabular}{|c|c|c|}
\hline \multicolumn{2}{|c|}{ Behavioral expression } & \multirow{2}{*}{$\begin{array}{l}\text { Detailed meaning } \\
\text { Leaders will actively listen to employees’ views, opinions and } \\
\text { ideas and make feedbacks to the information by use of their } \\
\text { body, attitude and emotion. }\end{array}$} \\
\hline 1 & Listening & \\
\hline 2 & Empathy & Leaders will consider their employees. \\
\hline 3 & Perception & Sharply perceive ethics and value behind the event \\
\hline 4 & Persuasion & $\begin{array}{l}\text { Leaders will influence employees' behaviors through rational } \\
\text { and convincing persuasion, rather than their power. }\end{array}$ \\
\hline 5 & Authorization & $\begin{array}{l}\text { Leaders will authorize employees with job autonomy and } \\
\text { decision-making right. }\end{array}$ \\
\hline 6 & Prediction & $\begin{array}{c}\text { Foresee possible outcomes in a specific circumstance in } \\
\text { advance }\end{array}$ \\
\hline 7 & Looking after & Keep favorable trust in the organization \\
\hline 8 & Commitment & $\begin{array}{l}\text { Promise all employees individual and career development } \\
\text { possibility }\end{array}$ \\
\hline 9 & Construction & Construct social groups in the organization \\
\hline
\end{tabular}

\section{Advantages of servant leadership}

There are diversified approaches for servant leadership to bring potential benefits for hotels. In combination of their prominent influence on hotels and hotel environment, this paper mainly pays close attention to two features: authorization and looking after.

\section{Authorization, trust and respect}

Trust is not generated naturally, but generated through authorization and value sharing. No leadership style is better than authorization in terms of serving employees. Meanwhile, authorization also motivates employees to be responsible for their decisions and behaviors. Authorization not just leads to changes in employees' responsibilities and rights. Similarly, leaders' responsibilities and rights are also altered. Authorization requires leaders trusting their employees' ability and respecting their decisions. (Sternberg 1992; Washington, Sutton, and Field 2006) Servant leadership regards employees as conscientious organization members and focuses on how to support them and discover their demands. Servant leaders who trust their employees more expect employees to mobilize their work initiative so as to reach better working effects and will encourage employees to further generate empathy effect for colleagues and customers. Large quantities of researches point out that trust generated from servant leadership practice will promote generation of organizational citizenship behavior and internal team ideology in working places (Ehrhart 2004, 6). 


\section{Ethicality practice of global hotel industry}

Among all researches on servant leadership, the articles about ethicality practice are very limited. However, with global development, many industries pay attention to ethicality behaviors of servant leadership in development. Servant leadership contributes to establishing ethicality practice. When organizational power excessively concentrates, ethic risks will inevitably appear. Under the condition of power concentration, when leaders lack self-reflection and moral idea, immoral results may easily occur, because direct and simple effects of individual behaviors. Servant leadership and transformational leadership emphasize authorization more than previous leadership styles. Transformational leadership motivates employees through leaders' individual charm or goal prospect. Driven by the goal, immoral risks may be implied. Leadership foundation of servant leaders is mutual benefit. Persuasion, authorization and commitment of servant leaders help employees experience the consistency of common goal and individual objective. In global hotel industry, the relationship between economic development in diverse regional cultures and regions and hotel group is also similar to the common objective of employees and the organization. Based on mutual benefit of servant leadership and long-term continuous development goal, hotel group can adapt current global development environment.

\section{Cultivation of servant leaders by hotels}

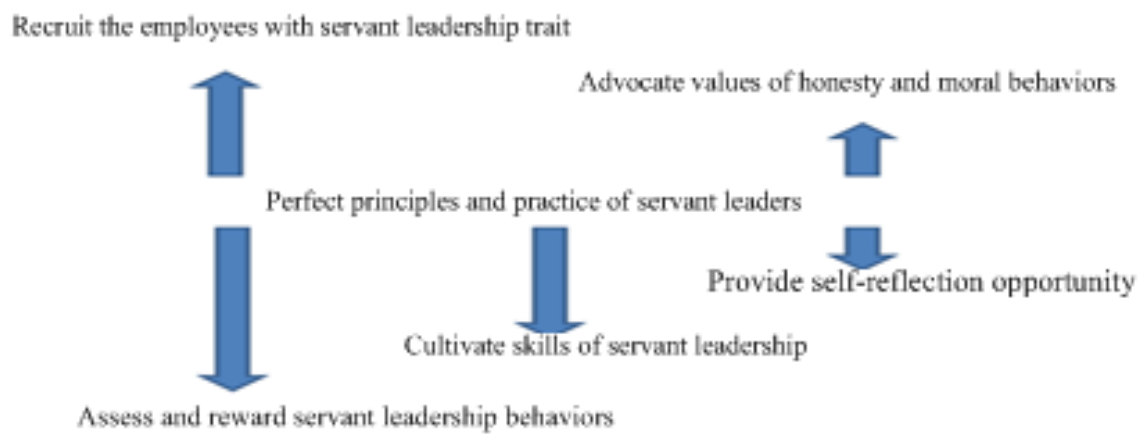

Table 2 Perfection of servant leaders by hotels

\section{Recruit the employees with servant leadership trait}

Hotels may enhance servant leadership philosophy of enterprises through interview, training and stressing importance of Integrity and organizational behaviors. Hotels should pay attention to recruiting the employees with servant leadership trait from the beginning and train them to servant leaders. In the interview, correct questions and questing ways can help us identify these people. They own individual accountability and strong service commitment.

\section{Advocate values of honesty and moral behaviors}

This requires senior managers of hotels firstly cognizing and understanding value and function of servant leadership and establishing servant leadership awareness. Then, senior managers should convey values of honesty and moral behaviors to other managers. Hotel managers should firm belief and establish examples for managers at each level through their own servant leadership behaviors. Excellent servant leaders are the examples of all managers of hotel group. Hotels may regularly appraise and elect servant leaders with integrity and outstanding morality performance according to assessment results of managers' servant leadership after widely soliciting senior managers of hotels, employees and customers. Besides, it is required to conduct vigorous propaganda and call on all employees to learn from them.

\section{Provide self-reflection opportunity}

Once the applicants are employed, the next task of hotel enterprises is to help potential servant leaders to shape their ethic features and behaviors. It is required to help them expand field of vision, 
pay attention to current social environment or benefit and own global, diversified and sustainable development perspective. It is also necessary to differentiate personal interests and personal interests through effective performance management means and help them understand responsibilities and obligations as well as functions of leadership post through system, customer demand, teamwork and service quality. Servant leaders should more clearly cognize the power of becoming leaders. Effective leaders grow internally.

\section{Cultivate skills of servant leadership}

Hotels should guide managers to better grasp relevant skills through carrying out skill training of servant leadership. Generally, skill training of servant leadership mainly starts from five aspects:

Firstly, correct self-positioning. Leaders should position themselves as a server, instead of power owner.

Secondly, correct motivation. Leaders should regard serving others rather than managing or gaining prestige as their behavior starting point.

Thirdly, correct method. Leaders should own leadership skills of listening, empathy, healing and persuasion etc.

Fourthly, correct influence. Servant leaders should stimulate others, reflect core value of hotels and make others willing to mobilize their initiative for excellent working performance.

Fifthly, correct personality characteristics. Under all environments, servant leaders can firm their belief and provide open and sincere feedback for employees.

\section{Assess and reward servant leadership behaviors}

Hotels should attach importance to servant leadership behavior and effect assessment, reward and promote servant managers according to assessment result. Assessment perspectives should be diversified to ensure assessment fairness. For example, employee satisfaction, demission rate, teamwork efficiency and customer satisfaction are mainly applied to assess servant leadership effects of managers. In addition, hotels should inform managers of the assessment result in time. Hotels may indicate the importance of the assessment and make managers know evaluation of employees for their servant leadership behaviors so as to help them improve work.

\section{Acknowledgments}

This study is funded by Shanghai innovative scientific research fund program (12YS196), Shanghai Educational Development Foundation (Chenguang scientific research fund) and Shanghai Young talent training plan (SHSF015).

\section{References}

[1] Ehrhart, M. G. 2004. Leadership and procedural justice climate as antecedents of unit-level organizational citizenship behavior. Personnel Psychology, 57 (1): 61-94.

[2] Judi Brownell, Leadership in the Service of Hospitality, Cornell Hospitality Quarterly, 2010 (51): 363

[3] Moore, B. V. 1927. The May conference on leadership. Personnel Journal, 69 (1): 122-35.

[4] Mann, R. D. 1959. A review of the relationships between personality and performance in small groups. Psychological Bulletin, 56:241-70.

[5] Van Velsor, E., and E. Ascalon. 2008. The role and impact of leadership development in supporting ethical action in organizations. Journal of Management Development, 27 (2): 187-95.

[6] Patterson, K. A. 2003. Servant leadership: A theoreticalmodel. Dissertation, Regent University, Virginia Beach,VA. AAT 3082719. 
[7] Washington, R. R., C. D. Sutton, and H. S. Field. 2006. Individual differences in servant leadership: The roles of values and personality. Leadership \& Organization Development Journal, 27 (8): 700-716.

[8] Ling Qian, Shaping and cultivating servant leaders. Human Resource Development of China, 2007.06: p42-65

[9] Wang Chunxiao, Ling Qian, Zhang Xiujuan, Design and inspection of servant leadership scale. Nankai Business Review, 2009 (3): p94-103 